\title{
Thyrotoxic crisis following eclampsia and induction of labour
}

\author{
V. MENON† \\ M.B.B.S., M.R.C.O.G.
}

\author{
W. W. McDougall $\ddagger$ \\ F.R.C.S. (Edin.), F.R.C.O.G.
}

\author{
B. A. LeAtherdale* \\ M.R.C.P., D.R.C.O.G.
}

\begin{abstract}
Department of $\uparrow$ Clinical Endocrinology, *Department of Medicine, Birmingham and Midland Hospital for Women, and $\ddagger$ Department of Obstetrics \& Gynaecology, Dudley Road Hospital, Birmingham B11 $4 H L$
\end{abstract}

\begin{abstract}
Summary
A patient was diagnosed to be thyrotoxic and commenced on medications, but it was not known that she was 13 weeks pregnant at the time. She failed to take the medications and presented at 25 weeks with eclampsia and thyrotoxic crisis. Her management is discussed.
\end{abstract}

\section{Introduction}

Hyperthyroidism has been estimated to complicate approximately 2 in 1000 pregnancies in the United Kingdom (Niswander and Gordon, 1972; Burrow, 1977; Montgomery and Harley, 1977). Thyrotoxic crisis is now rare. A case is described in which pregnancy was complicated by both eclampsia and a subsequent thyrotoxic crisis.

\section{Case report}

A 28-year-old Indian woman presented to the surgical out-patient clinic with complaints of weightloss and a neck swelling. On examination the surgeon found that the patient had a smooth goitre, lid lag and a tachycardia of 120 per min. The serum thyroxine (T4) level was $215 \mathrm{nmol} / 1$ (normal 60-135). She was started on carbimazole $10 \mathrm{mg}$ three times daily. It was however, not known that she was 13 weeks pregnant at this time. She did not turn up for review 4 weeks later.

Nine weeks after initial presentation to the surgical out-patient department, she attended the antenatal booking clinic in her 5 th pregnancy at 22 weeks gestation. She had had four previous uneventful pregnancies. The uterine size corresponded with dates and the blood pressure was $120 / 80 \mathrm{mmHg}$ and the pulse rate 110 per min. She had a smooth goitre and lid lag was present. She claimed to be taking carbimazole regularly (though this later proved to be false). Thyroid function tests were not done.

Three weeks after booking she had two fits and was admitted as an obstetric emergency. On arrival blood pressure was $190 / 105 \mathrm{mmHg}$, pulse rate was 140 per min, and there was heavy proteinuria with ankle oedema. Eclampsia was diagnosed and treatment started with a constant infusion of $0.8 \%$ chlormethiazole and hydralazine $40 \mathrm{mg}$ in $50 \mathrm{ml}$ of $5 \%$ dextrose intravenously. After an epidur anaesthetic block, labour was induced with extraz amniotic prostaglandin. Eight hours later a female fetus was aborted.

Following delivery her condition was stable for approximately $7 \mathrm{hr}$, when she developed extreme restlessness despite the chlormethiazole. She was tachypnoeic with a tachycardia of 200 per min, blood pressure was $170 / 95 \mathrm{mmHg}$, and there were bilateral basal lung crepitations. She became unrouseable and chlormethiazole was stopped. There were no localizing signs in the central nervous system. Cardiac failure was treated initially with digoxin $0.5 \mathrm{mg}$ and frusemide $40 \mathrm{mg}$ intravenously, but her condition did not improve. Thyrotoxic crisis was suspected and treatment started with propranolol $40 \mathrm{mg}$ four times daily, carbimazole $15 \mathrm{mg}$ three times daily, digoxin $0.25 \mathrm{mg}$ (two doses), and 5 drops of Lugol's iodine, all given through a Ryle's tube. She gradually improved and $40 \mathrm{hr}$ postpartum was fully conscious with a normal blood pressure and no signs of cardiac failure, although a tachycardia of 100 per min persisted. She had passed 12.5 litres of urine in the preceding $24 \mathrm{hr}$.

Carbimazole and propranolol were continued during the puerperium and she was discharged 7 days after admission. Thyroid function tests on admission confirmed thyrotoxicosis-T4 $146 \mathrm{nmol} / \mathrm{l}$ (60-135), T3 uptake $66 \%$ (93-117), free thyroxine index (FTI) $17(3 \cdot 4-13)$. 


\section{Discussion}

This patient was found to be thyrotoxic in early pregnancy before booking but did not take her medication. Thyrotoxic crisis usually results from inadequate treatment (Ingbar, 1966), and can be precipitated by infection, trauma, surgical emergencies, eclampsia or labour (Kamm et al., 1963). In this patient, the thyrotoxic crisis appears to have been precipitated by both eclampsia and inadequate antithyroid therapy. The latter was mainly due to the patient's failure to take the prescribed medication. This fact was not appreciated by the obstetric staff at booking as she appeared controlled clinically and when, for the same reason, thyroid function tests were not done. If these had been done, her thyrotoxic state would have been discovered and the subsequent thyrotoxic crisis might have been prevented.

Thyrotoxic crisis can be life-threatening, and is characterized by extreme irritability, delirium, coma, fever, tachycardia, hypotension, vomiting and diarrhoea (Komins, Snyder and Schwarz, 1975). High output cardiac failure frequently results. Urgent treatment is required and should include oxygenation and rehydration as well as general supportive measures. Specific treatment is designed to prevent secretion of thyroid hormones and to modify their effects on endorgans (Harrison, 1977). Antithyroid drugs will prevent hormone synthesis and Lugol's iodine will inhibit secretion of already synthesized hormones. Propranolol counteracts the peripheral effects mainly by its effect as a beta- adrenergic blocker. With combined treatment the hypermetabolic state can be controlled, and its effectiveness was dramatically illustrated by the excellent response in our patient.

This case illustrates the dangers of untreated thyrotoxicosis in pregnancy and it also emphasizes the utmost importance of controlling thyrotoxicosis rapidly during pregnancy. This should preferably be done by a physician experienced in the handling of thyroid problems.

\section{References}

BurRow, G.N. (1977) Thyroid and parathyroid function in pregnancy. In: Endocrinology of Pregnancy, 2nd edn. (Ed by Fuchs, F. \& Klopper, A.), p. 258. Harper and Row, Hagerstown, Maryland.

HARrison, T. R. (1977) Diseases of the thyroid. In: Principles of Medicine, 8th edn. (Ed by Thorns, G.W., Adams, R.D., Braunwald, E., Isselbacher, K.J. \& Petersdorf, R.G.), pp. 501-514. McGraw-Hill, New York.

INGBAR, S.H. (1966) Thyrotoxic storm. New England Journal of Medicine, 274, 1252.

Kamm, M.L., Weaver, J.C., Page, E.P. \& Chappell, C.C. (1963) Acute thyroid storm precipitated by labour. Obstetrics and Gynecology, 21, 460.

Komins, J.I., SNYDER, P.J. and Schwarz, R.H. (1975) Hyperthyroidism in pregnancy. Obstetrics and Gynecology Survey, 30, 527.

Montgomery, D.A.D. \& HaRley, J.M.G. (1977) Endocrine disorders. In: Clinics in Obstetrics and Gynaecology. Vol. 4. (Ed by Whitfield, C.R.), p. 339. W.B. Saunders, Philadelphia, London, Toronto.

Niswander, K.R. \& GoRdon, M. (1972) The Women and their Pregnancies, p. 246. W.B. Saunders, Philadelphia, London, Toronto. 